\title{
Eilat virus displays a narrow mosquito vector range
}

\author{
Faroog Nasar ${ }^{1,2}$, Andrew D Haddow ${ }^{2}$, Robert B Tesh ${ }^{1}$ and Scott C Weaver ${ }^{1 *}$
}

\begin{abstract}
Background: Most alphaviruses are arthropod-borne and utilize mosquitoes as vectors for transmission to susceptible vertebrate hosts. This ability to infect both mosquitoes and vertebrates is essential for maintenance of most alphaviruses in nature. A recently characterized alphavirus, Eilat virus (EILV), isolated from a pool of Anopheles coustani s.l. is unable to replicate in vertebrate cell lines. The EILV host range restriction occurs at both attachment/entry as well as genomic RNA replication levels. Here we investigated the mosquito vector range of EILV in species encompassing three genera that are responsible for maintenance of other alphaviruses in nature.

Methods: Susceptibility studies were performed in four mosquito species: Aedes albopictus, A. aegypti, Anopheles gambiae, and Culex quinquefasciatus via intrathoracic and oral routes utilizing EILV and EILV expressing red fluorescent protein (-eRFP) clones. EILV-eRFP was injected at $10^{7} \mathrm{PFU} / \mathrm{mL}$ to visualize replication in various mosquito organs at 7 days post-infection. Mosquitoes were also injected with EILV at $10^{4}-10^{1} \mathrm{PFU} / \mathrm{mosquito}$ and virus replication was measured via plaque assays at day 7 post-infection. Lastly, mosquitoes were provided bloodmeals containing EILV-eRFP at doses of $10^{9}, 10^{7}, 10^{5} \mathrm{PFU} / \mathrm{mL}$, and infection and dissemination rates were determined at 14 days post-infection.

Results: All four species were susceptible via the intrathoracic route; however, replication was 10-100 fold less than typical for most alphaviruses, and infection was limited to midgut-associated muscle tissue and salivary glands. A. albopictus was refractory to oral infection, while A. gambiae and C. quinquefasciatus were susceptible only at $10^{9} \mathrm{PFU} / \mathrm{mL}$ dose. In contrast, $A$. aegypti was susceptible at both $10^{9}$ and $10^{7} \mathrm{PFU} / \mathrm{mL}$ doses, with body infection rates of $78 \%$ and $63 \%$, and dissemination rates of $26 \%$ and $8 \%$, respectively.

Conclusions: The exclusion of vertebrates in its maintenance cycle may have facilitated the adaptation of EILV to a single mosquito host. As a consequence, EILV displays a narrow vector range in mosquito species responsible for the maintenance of other alphaviruses in nature.
\end{abstract}

Keywords: Alphavirus, Eilat virus, Host range

\section{Background}

The genus Alphavirus in the family Togaviridae is comprised mostly of arthropod-borne viruses that utilize mosquitoes as vectors for transmission to diverse vertebrate hosts including equids, birds, amphibians, reptiles, rodents, pigs, humans, and non-human primates [1]. Alphaviruses also have a broad mosquito host range and can infect many species encompassing at least eight genera (Aedes, Culex, Anopheles, Culiseta, Haemagogus, Mansonia, Verrallina and Psorophora spp.) [2-6]. Recently,

\footnotetext{
* Correspondence: sweaver@utmb.edu

'Institute for Human Infections and Immunity, Center for Tropical Diseases, and Department of Pathology, University of Texas Medical Branch, Galveston, TX 77555, USA

Full list of author information is available at the end of the article
}

a newly characterized alphavirus, Eilat virus (EILV), isolated from a pool of Anopheles coustani s.I. mosquitoes was described [7]. EILV is unable to infect and replicate in vertebrate cell lines but can readily replicate in insect cells [7]. The vertebrate host restriction is present at both attachment/entry as well as genomic RNA replication levels $[7,8]$. EILV is the first "insect-only" alphavirus described and represents a new complex within the genus $[7,8]$.

The lack of vertebrate hosts in its maintenance cycle has likely facilitated EILV adaptation to a single mosquito species; as a consequence EILV may display a narrow vector range. To investigate this hypothesis, we explored the in vivo vector host range of EILV by performing susceptibility studies in mosquitoes encompassing three genera that are responsible for maintenance of other 
alphaviruses in natural transmission cycles: Aedes albopictus, A. aegypti, Anopheles gambiae, and Culex quinquefasciatus.

\section{Methods}

\section{Cells and cell culture}

C7/10, an A. albopictus mosquito cell line, was propagated at $28^{\circ} \mathrm{C}$ with $5 \% \mathrm{CO}_{2}$ in Dulbecco's minimal essential medium (DMEM) containing 10\% (v/v) fetal bovine serum (FBS), sodium pyruvate $(1 \mathrm{mM})$, penicillin $(100 \mathrm{U} / \mathrm{mL})$, streptomycin $(100 \mu \mathrm{g} / \mathrm{mL})$, and $1 \%(\mathrm{v} / \mathrm{v})$ tryptose phosphate broth (Sigma).

\section{cDNA clones and rescue of infectious EILV}

EILV and EILV-eRFP cDNA clones were utilized to generate viruses for infection studies. The EILV-eRFP cDNA clone was generated by inserting eRFP under the control of a second subgenomic promoter downstream of the nsP4 gene via SnaB I and SgrA I restriction sites. Viruses were rescued as previously described [8].

\section{Stability of EILV-eRFP in C7/10 cells}

EILV-eRFP was serially passaged in $C 7 / 10$ cells at a multiplicity of infection (MOI) of $0.1 \mathrm{PFU} /$ cell, in triplicate. After the first passage, virus was titrated and the MOI was adjusted to 0.1 for subsequent passages. Five serial passages were performed, and passages one and five were titrated. Replicates of each passage were also fixed with $2 \mathrm{~mL}$ of $2 \%$ paraformaldehyde, and plaques expressing eRFP were counted via fluorescent microscopy followed by staining with crystal violet. The percentage of plaques expressing eRFP was calculated [(number of plaques expressing eRFP/total number of plaques) X 100]. Lastly, phase-contrast and fluorescent micrographs were taken of passage one and five virus infection of $\mathrm{C} 7 / 10$ cells.

\section{Plaque assay}

Virus titration was performed on $\sim 80 \%$ confluent C7/10 cell monolayers seeded overnight in six-well plates. Duplicate wells were infected with $0.1-\mathrm{mL}$ aliquots from serial 10-fold dilutions in growth medium, $0.4 \mathrm{~mL}$ of growth media was added to each well to prevent cell desiccation, and virus was adsorbed for $1 \mathrm{hr}$. Following incubation, the virus inoculum was removed, and cell monolayers were overlaid with $3 \mathrm{~mL}$ of a 1:1 mixture of $2 \%$ tragacanth (Sigma) and 2X MEM with 5\% FBS (v/v) containing $2 \%$ tryptose phosphate broth solution $(\mathrm{v} / \mathrm{v})$, penicillin $(200 \mathrm{U} / \mathrm{mL})$, and streptomycin $(200 \mu \mathrm{g} / \mathrm{mL})$. Cells were incubated at $28^{\circ} \mathrm{C}$ with $5 \% \mathrm{CO}_{2}$ for 3 days for plaque development, the overlay was removed, and monolayers were fixed with $3 \mathrm{~mL}$ of $10 \%$ formaldehyde in PBS for $30 \mathrm{~min}$. Cells were stained with $2 \%$ crystal violet in $30 \%$ methanol for $5 \mathrm{~min}$ at room temperature
(RT); excess stain was removed and plaques were counted.

\section{One-step replication kinetics}

Replication kinetics were assessed in C7/10 cells in triplicate. Infections were performed on 70\% confluent monolayers seeded overnight in T-25 $\mathrm{cm}^{2}$ flasks. Three replicates of EILV and EILV-eRFP were performed to achieve an MOI of $1 \mathrm{PFU} /$ cell and virus was adsorbed for $2 \mathrm{hr}$ at $28^{\circ} \mathrm{C}$. Following incubation, the inoculum was removed, monolayers were rinsed 5 times with RT DMEM to remove unbound virus, and $5 \mathrm{~mL}$ of growth medium was added to each flask. Aliquots of $0.5 \mathrm{~mL}$ were taken immediately afterward as "time 0" samples and replaced with $0.5 \mathrm{~mL}$ of fresh medium. Flasks were subsequently incubated at $28^{\circ} \mathrm{C}$ and additional time points were taken at $6,12,24$, and $48 \mathrm{hrs}$ post-infection (hpi). All samples were flash frozen in dry ice/ethanol bath and stored at $-80^{\circ} \mathrm{C}$.

\section{Mosquito species}

A. aegypti (Bangkok, Thailand), A. albopictus (Bangkok, Thailand), C. quinquefasciatus (Houston, TX, USA), and A. gambiae senso stricto (G3 strain) were utilized in these studies. A. aegypti and A. albopictus were kindly provided by the Armed Forces Research Institute of Medical Sciences (AFRIMS), Bangkok, Thailand.

\section{Intrathoracic mosquito infections}

Cohorts of 15-25 adult females, 5-6 days after emergence from the pupal stage, were cold-anesthetized and inoculated with $\sim 1 \mu \mathrm{L}$ of EILV at $10^{4}-10^{1} \mathrm{PFU} / \mathrm{mosquito}$ via the intrathoracic (IT) route. Mosquitoes were given $10 \%$ sucrose and held for an extrinsic incubation period of 7 days at $28^{\circ} \mathrm{C}$. Whole mosquitoes were placed in $1 \mathrm{~mL}$ of DMEM containing 20\% FBS (v/v), penicillin (200 U/mL), streptomycin $(200 \mu \mathrm{g} / \mathrm{mL}), 5 \mu \mathrm{g} / \mathrm{mL}$ amphotericin $\mathrm{B}$, and stored at $-80^{\circ} \mathrm{C}$. Samples were triturated using a Mixer Mill 300 (Retsch, Newtown, PA), centrifuged at $18,000 \times g$ for 5 minutes, and supernatants from each sample were analyzed via plaque assay.

\section{Imaging mosquito infection}

A. albopictus, A. aegypti, C. quinquefasciatus, and A. gambiae mosquitoes were injected via IT route with $\sim 1 \mu \mathrm{L}$ of EILV-eRFP at $10^{7} \mathrm{PFU} / \mathrm{mL}$ or with phosphate buffered saline (PBS). Mosquitoes were dissected 7 days post-injection and organs including the anterior and posterior midgut, hindgut, salivary glands, Malpighian tubules, and ovaries were imaged using fluorescent microscopy. PBS-injected mosquitoes were also imaged in the fluorescent field to obtain an exposure time to eliminate background fluorescence. Phase-contrast and fluorescent field photographs were taken of mosquito organs. 


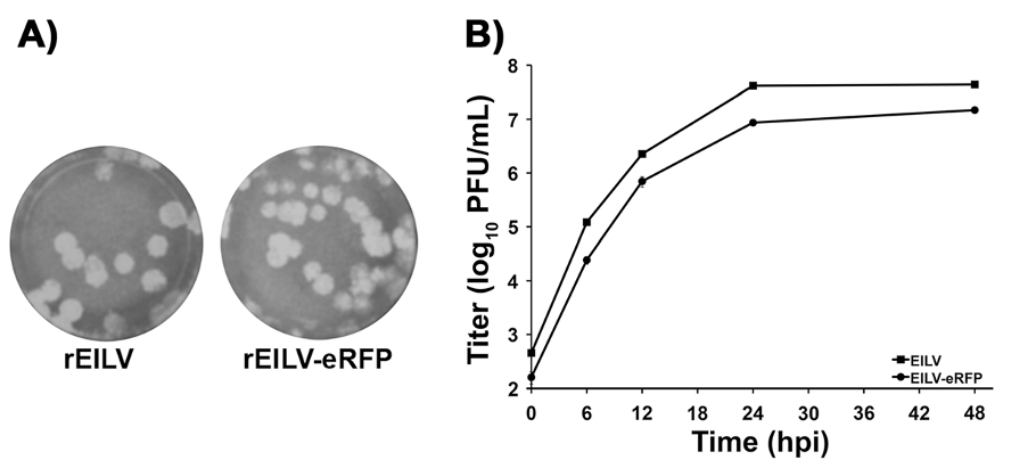

Figure 1 Comparison of plaque size (A) and replication kinetics (B) of EILV and EILV-eRFP in C7/10 cells (+/-S.D.).

\section{Oral mosquito infections}

Cohorts of 100 adult females 5-6 days after emergence from the pupal stage were sugar-starved for 24 hrs [6]. They were fed an artificial meal consisting of defibrinated sheep blood (Colorado Serum Company, Denver, CO) and EILV-eRFP at $10^{9}, 10^{7}$, and $10^{5} \mathrm{PFU} / \mathrm{mL}$ [6]. Mosquitoes were allowed to feed for $1 \mathrm{hr}$, and following feeding mosquitoes were coldanesthetized and sorted. Fully engorged mosquitoes at or higher than stage 3 were retained for the study [9]. Mosquitoes were given $10 \%$ sucrose in cotton balls and held for an extrinsic incubation period of 14 days at $28^{\circ} \mathrm{C}$.

\section{Mosquito processing}

Following extrinsic incubation, mosquitoes were coldanesthetized bodies and legs/wings were removed. Mosquito bodies and legs/wings were triturated separately in $500 \mu \mathrm{L}$ of $1 \mathrm{X}$ DMEM containing $20 \%$ FBS (v/v), penicillin $(200 \mathrm{U} / \mathrm{mL})$, streptomycin $(200 \mu \mathrm{g} / \mathrm{mL})$, and $5 \mu \mathrm{g} / \mathrm{mL}$ amphotericin B, using a Mixer Mill 300 (Retsch) [10]. Samples were centrifuged at $18,000 \times g$ for 5 minutes and supernatants from each sample were analyzed by RT-PCR, eRFP expression, and plaque assays. RT-PCR primers were designed in the nsP4 and capsid genes to flank the eRFP cassette.

\section{Results}

Plaque size, in vitro replication kinetics, and stability of eRFP cassette

EILV and EILV-eRFP assayed on C7/10 cells produced plaques similar in size $(\sim 3-$ to $4-\mathrm{mm}) 3$ days postinfection (dpi) (Figure 1A). Both EILV and EILV-eRFP displayed similar replication kinetics after infection with an MOI of 1; however, viral titers of EILV eRFP were $\sim 2-8$ fold lower than those of EILV (Figure 1B). To investigate the stability of eRFP cassette, EILV-eRFP was serially passaged 5 times in C7/10 cells at an MOI of 0.1. Viral titers at passage one and five were similar (6.1 vs. $6.5 \log _{10} \mathrm{PFU} / \mathrm{mL}$ ), and $99 \%$ of plaques expressed eRFP at passage one vs. $90 \%$ at passage five (Figure 2 and Table 1).

\section{Intrathoracic infection of mosquitoes}

To determine the susceptibility of four mosquito species (A. albopictus, A. aegypti, A. gambiae, and C. quinquefasciatus), they were injected via the IT route with $\sim 1 \mu \mathrm{L}$ of EILV-eRFP at $10^{7} \mathrm{PFU} / \mathrm{mL}$. Virus replication was detected by visualizing eRFP expression at $7 \mathrm{dpi}$ in various organs including anterior midgut, posterior midgut, hindgut, salivary glands, Malpighian tubules, and ovaries. Organ susceptibility to EILV-eRFP infection varied by species. The posterior midgut was consistently infected in all

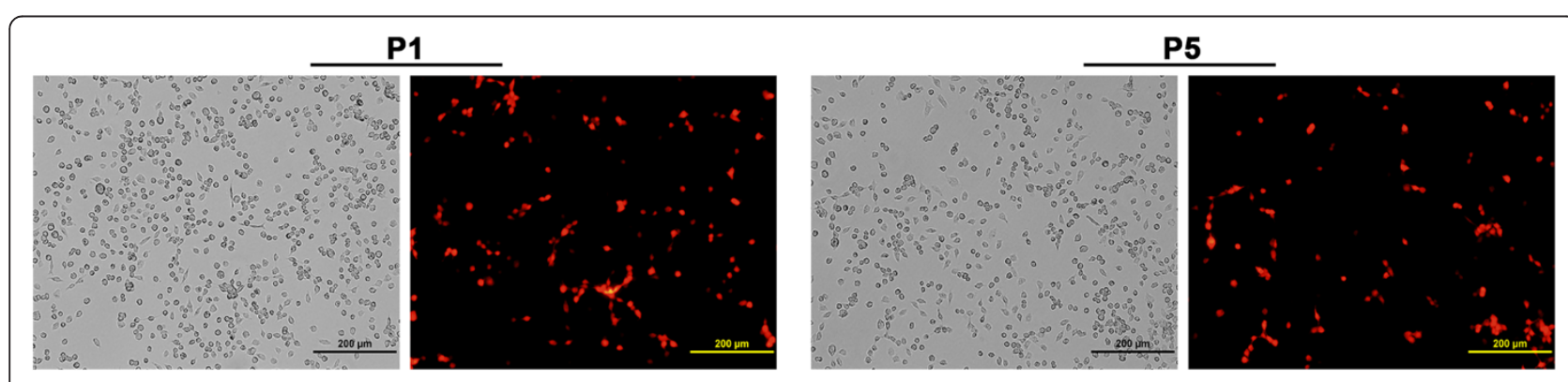

Figure 2 Stability of eRFP cassette in C7/10 cells after five serial passages. Phase-contrast and fluorescent photographs of passage one and five infection in $\mathrm{C} 7 / 10$ cells are shown. 
Table 1 Stability of eRFP cassette in C7/10 cells after five serial passages

\begin{tabular}{lcc}
\hline EILV-eRFP & $\begin{array}{c}\text { Titer } \\
\left(\log _{10} \text { PFU/ml) }\right. \\
(+/- \text { SD) }\end{array}$ & $\begin{array}{c}\text { \% of plaques } \\
\text { expressing eRFP }\end{array}$ \\
\hline Passage \#1 & $6.1(+/-0.18)$ & 99 \\
Passage \#5 & $6.5(+/-0.20)$ & 90 \\
\hline
\end{tabular}

Virus titers for passage one and five were generated with standard plaque assay. Percent of plaques expressing eRFP was determined by counting plaques expressing eRFP via fluorescent microscope and crystal violet staining.

species at rates of 70-100\% (Figure 3, Table 2, Additional file 1: Figure S1). The eRFP expression in the posterior midgut was more pronounced in the midgut-associated muscle tissue (Figure 3, Additional file 1: Figure S1). Salivary glands were the next most susceptible organ, with eRFP expression readily observed in all three Aedes and Culex species at frequencies of $70-90 \%$ (Figure 4, Table 2). Other organs, including the anterior midgut and Malpighian tubules, supported limited or no infection in $A$. albopictus and C. quinquefasciatus, whereas infection rates in both organs ranged from $30-50 \%$ in $A$. aegypti (Figure 5, Table 2). In contrast, virus replication was not detected in any organs except the posterior midgut of A. gambiae (Table 2). Lastly, virus replication could not be detected in the ovaries of any mosquito species (Table 2).

To determine the mosquito infectious dose $50 \%\left(\mathrm{ID}_{50}\right)$ via the IT route, all four species were injected with EILV at $10^{4}-10^{1} \mathrm{PFU} / \mathrm{mosquito}$. All species were susceptible at every dose with infection rates of $100 \%$ at 7 dpi (Figure 6 , Table 3). EILV readily replicated in all four species with a $~ 1,000$-fold increase in virus titers by $7 \mathrm{dpi}$ (Table 3 ). Thus, similar to other alphaviruses, the ID $_{50}$ of EILV via IT route is $<10 \mathrm{PFU} / \mathrm{mosquito}$, indicating a low threshold required to establish infection.

\section{Oral infection of mosquitoes}

To determine the oral ID $_{50}$, mosquitoes were fed artificial bloodmeals containing EILV-eRFP at $10^{9}, 10^{7}$, and $10^{5} \mathrm{PFU} / \mathrm{mL}$. Virus infection in the bodies and legs/wings was monitored via eRFP expression and plaque assay at $14 \mathrm{dpi}$. Infection rates in the bodies of A. albopictus ranged from $0 \%-8 \%$ at all 3 doses, with average virus titers of $1.5 \log _{10}$ PFU at both $10^{9}$ and $10^{7} \mathrm{PFU} / \mathrm{mL}$ doses (Table 4). Disseminated infection in the legs and wings was not detectable at any dose (Table 4). A. gambiae and C. quinquefasciatus were susceptible to infection at $10^{9} \mathrm{PFU} / \mathrm{mL}$ dose, with body infection rates of $29 \%$ and $30 \%$, respectively. Disseminated

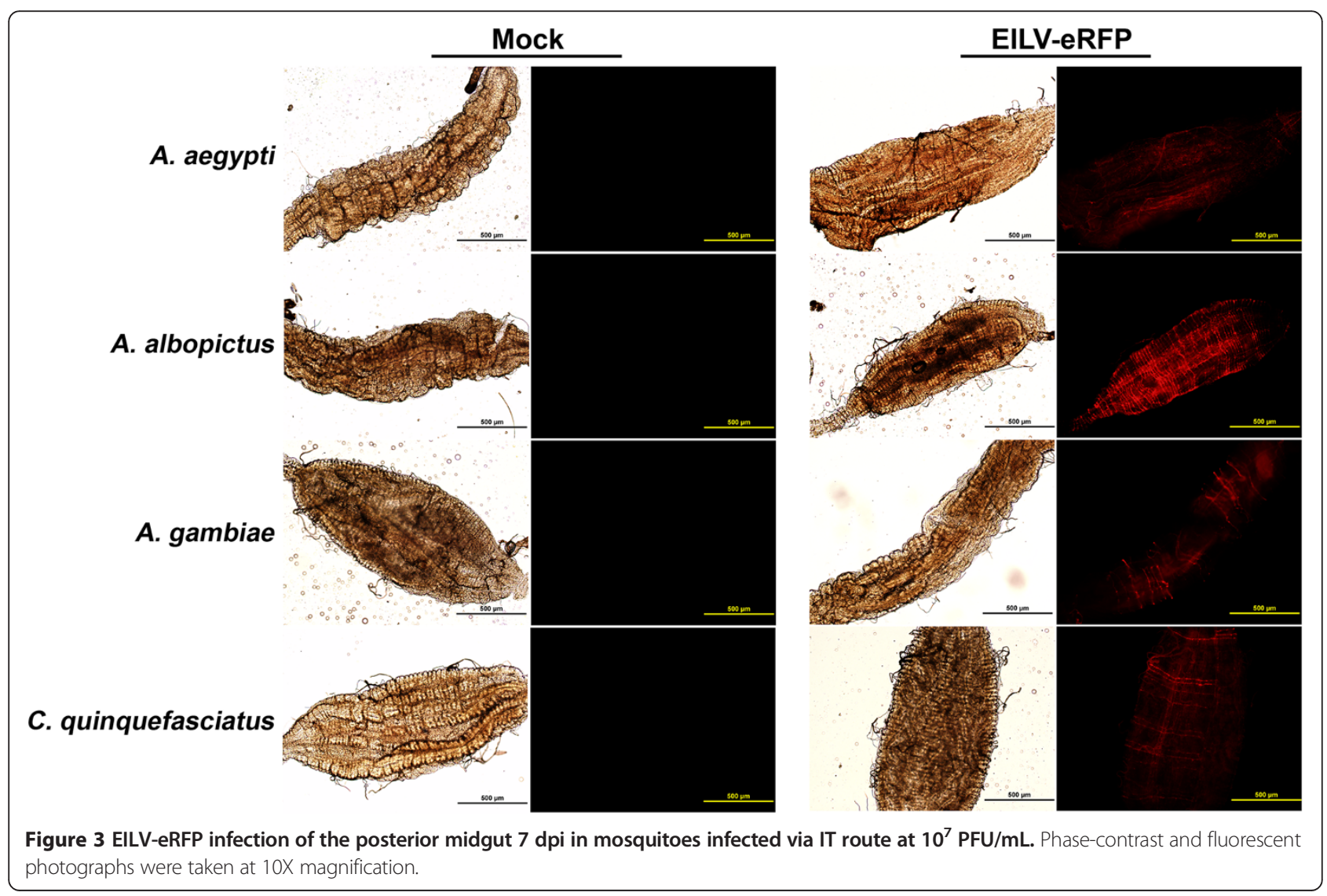


Table 2 EILV-eRFP infection of various mosquito organs 7 dpi

\begin{tabular}{|c|c|c|c|c|c|c|c|}
\hline \multirow[t]{2}{*}{ Species } & \multirow{2}{*}{$\begin{array}{l}\text { Intrathoracic dose } \\
\left(\log _{10} \text { PFUImL) }\right.\end{array}$} & \multicolumn{6}{|c|}{ Percent infected } \\
\hline & & Anterior midgut & Posterior midgut & Hindgut & Salivary glands & Malpighian tubules & Ovaries \\
\hline Aedes aegypti & 7.3 & 50 & 100 & 30 & 90 & 30 & 0 \\
\hline Aedes albopictus & 7.3 & 30 & 100 & 10 & 90 & 0 & 0 \\
\hline Anopheles gambiae & 7.3 & 0 & 70 & 0 & 0 & 0 & 0 \\
\hline Culex quinquefasciatus & 7.3 & 10 & 90 & 10 & 70 & 0 & 0 \\
\hline
\end{tabular}

10 mosquitoes/species were visualized with fluorescent microscopy.

infection could also be detected in the legs/wings with rates of $21 \%$ and $30 \%$, respectively (Table 4 ). Virus titers were similar in the bodies (1.6 vs. $1.6 \log _{10}$ PFU) as well as legs/wings (1.4 vs. $1.5 \log _{10}$ PFU) in both species (Table 4 ). At the $10^{7} \mathrm{PFU} / \mathrm{mL}$ dose, virus was detected in only $1 / 23$ A. gambiae and in none that ingested the $10^{5} \mathrm{PFU} / \mathrm{mL}$ dose. Virus infection could not be detected in the bodies or legs/wings of C. quinquefasciatus at $10^{7}$ and $10^{5}$ $\mathrm{PFU} / \mathrm{mL}$ doses (Table 4). In contrast to other species, A. aegypti was susceptible at both $10^{9}$ and $10^{7} \mathrm{PFU} / \mathrm{mL}$ doses, with body infection rates of $78 \%$ and $63 \%$, and dissemination rates of $26 \%$ and $8 \%$, respectively (Table 4 ). Similar virus titers were detected at both doses in the bodies (2.3 vs. $2.0 \log _{10}$ PFU) and legs/wings (2.2 vs. $1.5 \log _{10}$ PFU) (Table 4). Virus was not detected in either the bodies or legs/wings at the $10^{5} \mathrm{PFU} / \mathrm{mL}$ dose (Table 4).
To further investigate and compare infection rates, mosquito bodies from $10^{9} \mathrm{PFU} / \mathrm{mL}$ group were also screened by RT-PCR. Infection rates determined by eRFP expression and plaque assay were identical, whereas the utilization RT-PCR increased rates by $\sim 8 \%-28 \%$ for all species except $C$. quinquefasciatus (Table 5 ). The utilization of RT-PCR did not significantly change infection rates, however, smaller RT-PCR products could be visualized in some samples indicating loss of the eRFP cassette in vivo.

\section{Discussion}

Alphaviruses expressing fluorescent proteins are powerful tools for the study of mosquito infection [11-17]. The fluorescent protein cassettes expressed by engineered viruses [Sindbis (SINV) and chikungunya (CHIKV)] are

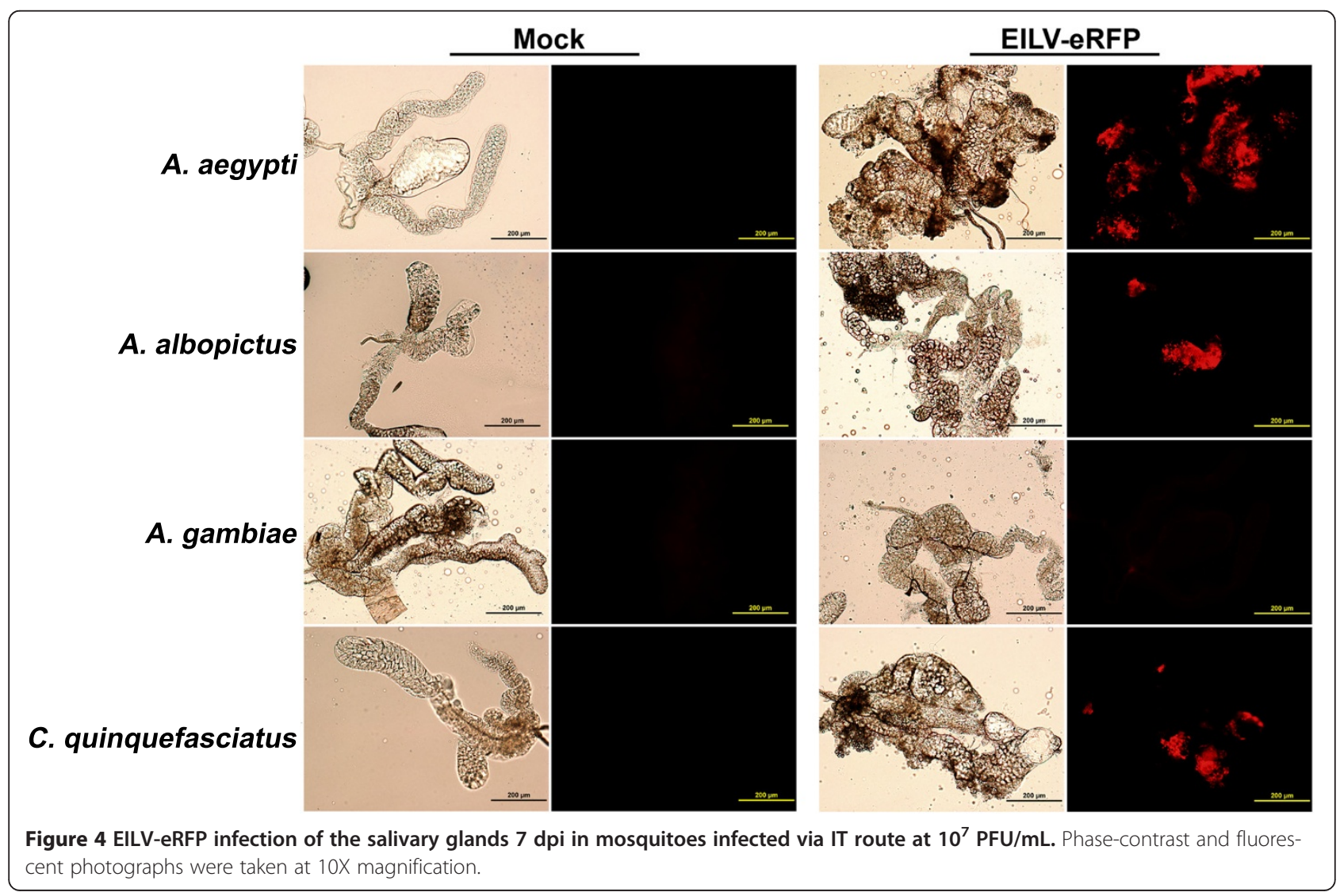




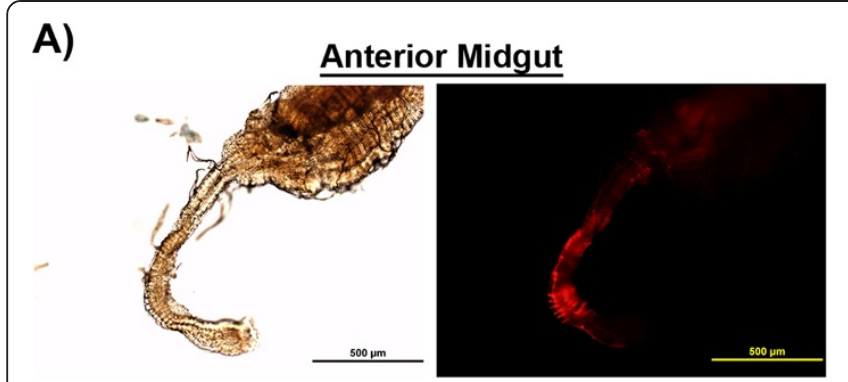

B)

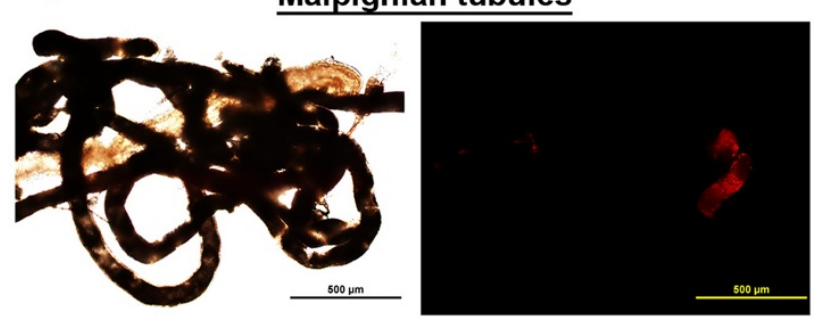

Figure 5 EILV-eRFP infection of the anterior midgut (A) and Malpighian tubules (B) 7 dpi in A. aegypti mosquitoes infected via IT route at $10^{7} \mathrm{PFU} / \mathrm{mL}$. Phase-contrast and fluorescent photographs were taken at $10 \mathrm{X}$ magnification.

stable both in vitro and in vivo $[11,12]$. These viruses display similar replication kinetics, infection and dissemination rates in mosquitoes as wild-type (wt) viruses without expression cassettes $[11,12]$. Consequently, they have been utilized to study infection dynamics, susceptibility of various mosquito organs, and potential bottlenecks during virus spread in vivo [11-17]. To perform similar studies, a EILV clone was engineered to express eRFP via an additional subgenomic promoter downstream of nsP4 gene, a genetic placement that has been shown to be stable both in vitro and in vivo for SINV and CHIKV $[11,12]$. EILV-eRFP displayed similar plaque size and replication kinetics relative to wt EILV in C7/10 cells. The eRFP cassette was shown to be stable in vitro over 5 serial passages, where $90 \%$ of the plaque population retained eRFP expression, a stability level comparable to previous results with SINV and CHIKV [11,12]. Virus replication could be visualized in the anterior and posterior midgut, hindgut, salivary glands, and Malpighian tubules. EILVeRFP could also be recovered from bodies and legs/wings collected 14 days after oral infection. Infection rates

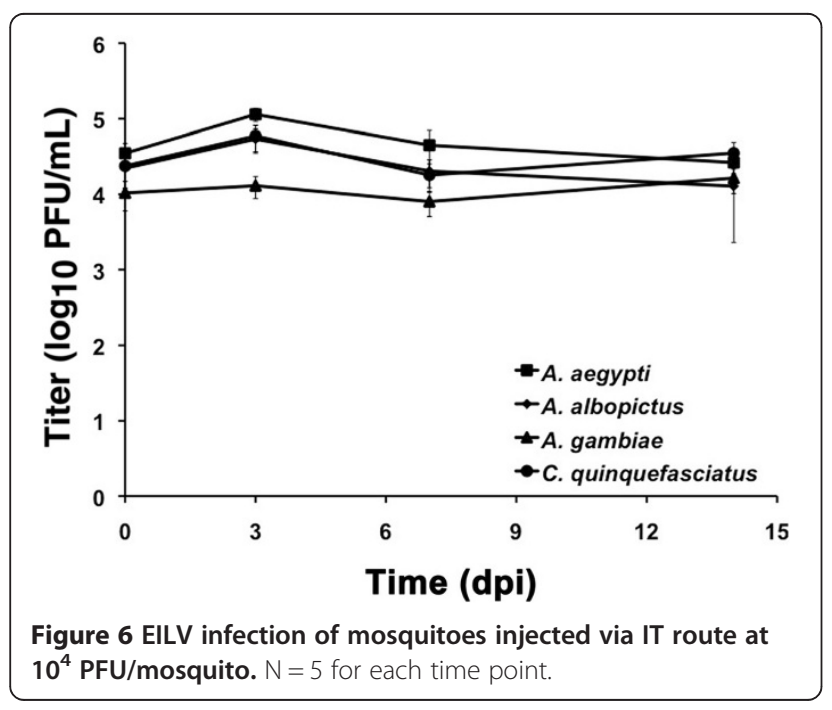

determined by eRFP expression and plaque assay were identical, indicating that the eRFP expression cassette was stable in vivo. Although the proportion of the virus population expressing eRFP in vivo at $14 \mathrm{dpi}$ was not determined, the detection of smaller RT-PCR products suggested that a portion of the virus population lost eRFP expression as observed in other studies $[12,13]$.

The aim of our work was to investigate infection of an insect-only alphavirus, EILV, in mosquito species encompassing three genera that are responsible for maintenance of alphaviruses in nature. Most mosquito species are susceptible to mosquito-borne alphavirus infection via the IT route; however, their oral susceptibility can vary greatly even within a species collected from different geographical locations [2,18-28]. Principal enzootic vectors utilized for transmission can often be infected orally with only a few infectious particles, while other species may require 100-1,000-fold higher dose to establish infection, or may be completely refractory to infection [18,25-28]. Our results were consistent with these findings, as all four species were susceptible to infection via the IT route. EILV infected several mosquito organs, with the posterior midgut and salivary glands consistently infected via the IT route in most species. Infection in the posterior midgut after IT inoculation was mainly associated with longitudinal and circular muscles, where the eRFP signal was more pronounced. The anterior midgut, hindgut, Malpighian tubules, and ovaries were either refractory to infection or supported minimal replication. A. aegypti, A. gambiae, and C. quinquefasciatus required high oral infectious dose $\left(10^{9} \mathrm{PFU} / \mathrm{mL}\right)$, and A. albopictus was almost completely refractory to oral infection. Lastly, EILV was able to disseminate from the midgut following oral exposure, albeit only after a large oral infectious dose $\left(10^{9} \mathrm{PFU} / \mathrm{mL}\right)$.

Mosquito-borne alphaviruses are maintained in nature in enzootic or endemic cycles between susceptible mosquito vectors and vertebrate hosts. In this two-host cycle, adaptive virus evolution may be constrained by trade-offs required for efficient infection of widely divergent hosts 
Table 3 Mosquito infection dose 50 (ID $\left.{ }_{50}\right)$ via IT route

\begin{tabular}{|c|c|c|c|}
\hline \multirow[t]{4}{*}{ Species } & \multirow{4}{*}{$\begin{array}{c}\text { Dose } \\
\text { ( } \log _{10} \text { PFU/mosquito) } \\
(+/-S D)\end{array}$} & \multicolumn{2}{|c|}{ Infection (7 dpi) } \\
\hline & & \multirow{3}{*}{$\%$ infected } & Titer \\
\hline & & & ( $\log _{10}$ PFU/mosquito) \\
\hline & & & $(+/-S D)$ \\
\hline \multirow[t]{4}{*}{ Aedes aegypti } & $4.5(+/-0.16)$ & 100 & $4.6(+/-0.15)$ \\
\hline & $3.7(+/-0.11)$ & 100 & $4.9(+/-0.07)$ \\
\hline & $2.4(+/-0.26)$ & 100 & $4.9(+/-0.08)$ \\
\hline & $1.3(+/-0.29)$ & 100 & $4.8(+/-0.15)$ \\
\hline \multirow[t]{4}{*}{ Aedes albopictus } & $4.3(+/-0.21)$ & 100 & $4.3(+/-0.18)$ \\
\hline & $3.3(+/-0.14)$ & 100 & $4.6(+/-0.25)$ \\
\hline & $2.3(+/-0.43)$ & 100 & $4.5(+/-0.14)$ \\
\hline & $1.0^{*}$ & 100 & $4.4(+/-0.19)$ \\
\hline \multirow[t]{4}{*}{ Anopheles gambiae } & $4.0(+/-0.18)$ & 100 & $3.9(+/-0.43)$ \\
\hline & $2.8(+/-0.18)$ & 100 & $4.1(+/-0.22)$ \\
\hline & $1.8(+/-0.38)$ & 100 & $4.1(+/-0.15)$ \\
\hline & $1.0^{*}$ & 100 & $4.3(+/-0.04)$ \\
\hline \multirow[t]{4}{*}{ Culex quinquefasciatus } & $4.1(+/-0.18)$ & 100 & $4.2(+/-0.25)$ \\
\hline & $3.1(+/-0.12)$ & 100 & $4.2(+/-0.24)$ \\
\hline & $1.8(+/-0.30)$ & 100 & $4.1(+/-0.30)$ \\
\hline & $1.0^{*}$ & 100 & $4.2(+/-0.31)$ \\
\hline
\end{tabular}

Mosquitoes were injected at doses ranging from $10^{4}-10^{1} \mathrm{PFU} / \mathrm{mosquito}$ of EILV. Whole mosquitoes were analyzed post-injection and 7 dpi at each dose via plaques assays. $\mathrm{N}=5$ for each time point. ${ }^{*}$ Samples were below the limit of detection ( $\left.10^{1} \mathrm{PFU} / \mathrm{mosquito}\right)$ for the plaque assay.

Table 4 Oral infection of mosquitoes with EILV-eRFP

\begin{tabular}{|c|c|c|c|c|c|}
\hline \multirow[t]{2}{*}{ Species } & \multirow{2}{*}{$\begin{array}{l}\text { Blood meal titer } \\
\left(\log _{10} \mathrm{PFU} / \mathrm{mL}\right)\end{array}$} & \multicolumn{2}{|c|}{ Body } & \multicolumn{2}{|c|}{ Legs/wings } \\
\hline & & $\%$ infected & $\begin{array}{c}\text { Titer } \\
\left(\log _{10} \text { PFU) }\right. \\
(+/-S D)\end{array}$ & $\%$ infected & $\begin{array}{c}\text { Titer } \\
\left(\log _{10} \text { PFU) }\right. \\
(+/-S D) \\
\end{array}$ \\
\hline \multirow[t]{3}{*}{ Aedes aegypti } & 8.9 & $78(18 / 23)$ & $2.3(+/-0.87)$ & $26(6 / 23)$ & $2.2(+/-0.73)$ \\
\hline & 6.9 & $63(15 / 24)$ & $2.0(+/-0.83)$ & $8(2 / 24)$ & $1.5(+/-0.34)$ \\
\hline & 5.0 & $0(0 / 15)$ & ND & $0(0 / 15)$ & ND \\
\hline \multirow[t]{3}{*}{ Aedes albopictus } & 8.9 & $7(2 / 27)$ & $1.5(+/-0.16)$ & $0(0 / 27)$ & $1.0^{*}$ \\
\hline & 6.9 & $8(2 / 24)$ & $1.5(+/-0.19)$ & $0(0 / 24)$ & $1.0^{*}$ \\
\hline & 5.0 & $0(0 / 31)$ & ND & $0(0 / 31)$ & ND \\
\hline \multirow[t]{3}{*}{ Anopheles gambiae } & 8.8 & $29(4 / 14)$ & $1.6(+/-0.36)$ & $21(3 / 14)$ & $1.4(+/-0.10)$ \\
\hline & 6.9 & $4(1 / 23)$ & 1.3 & $4(1 / 23)$ & 1.3 \\
\hline & 5.7 & $0(0 / 15)$ & ND & $0(0 / 15)$ & ND \\
\hline \multirow[t]{3}{*}{ Culex quinquefasciatus } & 9.0 & $30(9 / 30)$ & $1.6(+/-0.55)$ & $30(9 / 30)$ & $1.5(+/-0.24)$ \\
\hline & 7.7 & $0(0 / 28)$ & $1.0^{*}$ & $0(0 / 28)$ & $1.0^{*}$ \\
\hline & 5.8 & $0(0 / 30)$ & ND & $0(0 / 30)$ & ND \\
\hline
\end{tabular}

Mosquito bodies and legs/wings were analyzed for eRFP expression and plaques assays in C7/10 cells. *Samples were below the limit of detection (10 $\left.{ }^{1} \mathrm{PFU} / \mathrm{mosquito}\right)$ for the plaque assay. 
Table 5 Comparison body infection rates via eRFP expression, plaque assay, and RT-PCR

\begin{tabular}{|c|c|c|c|c|}
\hline \multirow[t]{2}{*}{ Species } & \multirow{2}{*}{$\begin{array}{c}\text { Oral dose } \\
\left(\log _{10} \mathrm{pfu} / \mathrm{mL}\right)\end{array}$} & \multicolumn{3}{|c|}{$\%$ bodies infected } \\
\hline & & eRFP & Plaque assay & RT-PCR \\
\hline Aedes aegypti & 8.9 & $78(18 / 23)$ & $78(18 / 23)$ & $87(20 / 23)$ \\
\hline Aedes albopictus & 8.9 & $7(2 / 27)$ & $7(2 / 27)$ & $15(4 / 27)$ \\
\hline Anopheles gambiae & 8.9 & $29(4 / 14)$ & $29(4 / 14)$ & $43(6 / 14)$ \\
\hline Culex quinquefasciatus & 8.9 & $30(9 / 30)$ & $30(9 / 30)$ & $30(9 / 30)$ \\
\hline
\end{tabular}

Percent of mosquito bodies positive at $14 \mathrm{dpi}$.

[29-34]. However, EILV is restricted at both attachment/ entry and RNA replication stages of infection in vertebrate cells, and is therefore unlikely to be maintained in a twohost cycle $[7,8]$. The lack of vertebrates in its maintenance likely removed the evolutionary "trade-off" pressures that typically constrain two-host alphaviruses from optimal adaptation to a single host. Assuming that vertical transmission is its main mode of maintenance in nature, EILV may have adapted to a single mosquito host, resulting in a narrow vector range. This species-specific adaptation and lack of a need for oral infection in nature could eliminate or greatly reduce EILV oral susceptibility even at high doses $\left(10^{9} \mathrm{PFU} / \mathrm{mL}\right)$ resulting in limited tissue susceptibility required of other arboviruses that must disseminate and infect the salivary glands for transmission. Our data support this hypothesis. EILV titers after IT infection were $\sim 10-100$ fold less than reported for other alphaviruses, and infection was limited mainly to midgut-associated muscle tissue and salivary glands [35-37]. Most of the mosquito species were either refractory or supported limited infection via the oral route even at $10^{9} \mathrm{PFU} / \mathrm{mL}$. Additionally, infection in the most susceptible species, A. aegypti, was limited to the midgut at both $10^{9}$ and $10^{7} \mathrm{PFU} / \mathrm{mL}$ doses, suggesting that EILV was unable to disseminate into the hemocoel. However, this hypothesis needs to be investigated further through field collections to determine the EILV host range in nature.

Natural maintenance of EILV presumably relies on vertical and possibly venereal transmission. These mechanisms are reported to occur for other alphaviruses; however, estimated rates are low and are consequently thought to play a minor role in natural maintenance [38-43]. Similarly, vertical and venereal transmission have been demonstrated for mosquito-only flaviviruses [44-46]. However, in contrast to alphaviruses, the vertical transmission rate of Culex flavivirus in naturally infected mosquitoes has been shown to be almost $100 \%$ and is consequently thought to play a major role in natural maintenance [45]. A critical step in the vertical transmission of insect-only viruses would involve infection of the ovaries. Accordingly, studies with Culex flavivirus have detected viral RNA in the ovaries of F1 progeny of infected females and intrathoracically infected mosquitoes [45]. However, we were unable to detect EILV infection in the ovaries of four mosquito species tested via the intrathoracic route. These data further support the narrow vector range hypothesis. The identification of principal vector species will enable studies to determine the mechanism/s of maintenance in nature.

EILV was isolated from a pool of A. coustani s.I. in a survey of the Negev desert in Israel during 1982-1984 [47]. Its apparent lack of a vertebrate host suggests that A. coustani s.I. may be the only mosquito species responsible for natural maintenance of EILV. If true, EILV would be only the second alphavirus described that utilizes Anopheles spp. as a natural vector. The other is o'nyongnyong virus (ONNV), an African alphavirus transmitted to humans by $A$. gambiae and A. funestus, which has caused large epidemics of severe arthralgia [48-51]. A. coustani s.I. is found in Africa and parts of the Middle East; however, it is not a well-studied species [52]. Limited data indicate that it can exhibit both zoophilic and anthropophilic feeding behavior [53,54]. It is also a secondary vector for malaria parasite transmission in Africa but its role in transmission of other human and/or animal pathogens remains poorly understood [55-58]. Whether A. coustani s.I. is the principal species responsible for maintenance of EILV in nature needs to be investigated further by virus isolation from field collected mosquito, larvae and eggs. It is possible that A. coustani s.I. is not the principal vector, and other mosquito species near the sites of the original survey study need to be sampled in order to identify the principal vector [47].

\section{Conclusions}

The present study shows that the exclusion of vertebrates in its maintenance cycle likely facilitated the adaptation of EILV to a single mosquito host. As a consequence, EILV displays a narrow vector range in mosquito species responsible for the maintenance of other alphaviruses in nature.

\section{Additional file}

\footnotetext{
Additional file 1: Figure S1. EILV-eRFP infection of the posterior midgut $7 \mathrm{dpi}$ in mosquitoes infected via IT route at $10^{7} \mathrm{PFU} / \mathrm{mL}$. Phase-contrast and fluorescent photographs were taken at 40X magnification.
} 


\section{Competing interests}

The authors declare that they do not have any competing interests.

\section{Authors' contributions}

FN, ADH, RBT, and SCW designed experiments and interpreted results. FN and $\mathrm{ADH}$ conducted experiments. FN and SCW wrote and prepared the manuscript. All authors read and approved the final version of the manuscript.

\section{Acknowledgements}

We thank Alongkot Ponlawat, Richard Jarman and Jason Richardson of the Armed Forces Research Institute of Medical Sciences (AFRIMS), Bangkok, Thailand for kindly providing A. aegypti and A. albopictus mosquitoes. We also thank Jing $H$. Huang for her technical assistance with mosquito experiments. This work was supported by National Institutes of Health Contract HHSN2722010000401/HHSN27200004/D04 (to R.B.T.).

\section{Author details}

${ }^{1}$ Institute for Human Infections and Immunity, Center for Tropical Diseases, and Department of Pathology, University of Texas Medical Branch, Galveston, TX 77555, USA. ${ }^{2}$ Present Address: Virology Division, United States Army Medical Research Institute of Infectious Diseases, 1425 Porter Street, Frederick, MD 21702, USA.

Received: 14 July 2014 Accepted: 6 December 2014

Published online: 17 December 2014

\section{References}

1. Griffin DE: In Alphaviruses. In Fields Virology. 5th edition. Edited by Fields BN, Knipe DM, Howley PM. New York: Lippincott-Raven: 1023-1068.

2. Karabatsos $\mathrm{N}$ : International catalog of arboviruses including certain other viruses of vertebrates. 3rd edition. San Antonio, TX: American Society of Tropical Medicine and Hygiene; 1985.

3. Jupp PG, McIntosh BM, Dos Santos I, DeMoor P: Laboratory vector studies on six mosquito and one tick species with chikungunya virus. Trans $R$ Soc Trop Med Hyg 1981, 75(1):15-19.

4. Webb CE, Doggett SL, Ritchie SA, Russell RC: Vector competence of three Australian mosquitoes, Verrallina carmenti, Verraullina lineata, and Mansonia septempunctata (Diptera: Culicidae), for Ross River virus. J Med Entomol 2008, 45(4):737-740.

5. Mendez W, Liria J, Navarro JC, Garcia CZ, Freier JE, Salas R, Weaver SC, Barrera R: Spatial dispersion of adult mosquitoes (Diptera: Culicidae) in a sylvatic focus of Venezuelan equine encephalitis virus. J Med Entomol 2001, 38(6):813-821.

6. Ortiz DI, Anishchenko M, Weaver SC: Susceptibility of Psorophora confinnis (Diptera: Culicidae) to infection with epizootic (subtype IC) and enzootic (subtype ID) Venezuelan Equine encephalitis viruses. J Med Entomol 2005, 42(5):857-863.

7. Nasar F, Palacios G, Gorchakov RV, Guzman H, Da Rosa AP, Savji N, Popov VL, Sherman MB, Lipkin WI, Tesh RB, Weaver SC: Eilat virus, a unique alphavirus with host range restricted to insects by RNA replication. Proc Natl Acad Sci U S A 2012, 109(36):14622-14627.

8. Nasar F, Gorchakov RV, Tesh RB, Weaver SC: Eilat virus host range restriction is present at multiple levels of virus life cycle. J Virol 2014, in press.

9. Pilitt DR, Jones JC: A qualitative method for estimating the degree of engorgement of Aedes aegypti adults. J Med Entomol 1972, 9(4):334-337.

10. Smith DR, Adams AP, Kenney JL, Wang E, Weaver SC: Venezuelan equine encephalitis virus in the mosquito vector Aedes taeniorhynchus: infection initiated by a small number of susceptible epithelial cells and a population bottleneck. Virology 2008, 372(1):176-186.

11. Tsetsarkin K, Higgs S, McGee CE, De Lamballerie X, Charrel RN, Vanlandingham DL: Infectious clones of chikungunya virus (La Réunion isolate) for vector competence studies. Vector Borne Zoonotic Dis 2006, 6(4):325-337.

12. Pierro DJ, Myles KM, Foy BD, Beaty BJ, Olson KE: Development of an orally infectious Sindbis virus transducing system that efficiently disseminates and expresses green fluorescent protein in Aedes aegypti. Insect Mol Biol 2003, 12(2):107-116.

13. Brault AC, Foy BD, Myles KM, Kelly CL, Higgs S, Weaver SC, Olson KE, Miller $B R$, Powers AM: Infection patterns of o'nyong nyong virus in the malaria-transmitting mosquito, Anopheles gambiae. Insect Mol Biol 2004, 13(6):625-635.

14. Vanlandingham DL, Tsetsarkin K, Hong C, Klingler K, McElroy KL, Lehane MJ, Higgs S: Development and characterization of a double subgenomic chikungunya virus infectious clone to express heterologous genes in Aedes aegypti mosquitoes. Insect Biochem Mol Biol 2005, 35(10):1162-1170.

15. Higgs S, Traul D, Davis BS, Kamrud KI, Wilcox CL, Beaty BJ: Green fluorescent protein expressed in living mosquitoes-without the requirement of transformation. Biotechniques 1996, 21(4):660-664.

16. Olson KE, Myles KM, Seabaugh RC, Higgs S, Carlson JO, Beaty BJ: Development of a Sindbis virus expression system that efficiently expresses green fluorescent protein in midguts of Aedes aegypti following per os infection. Insect Mol Biol 2000, 9(1):57-65.

17. Smith DR, Arrigo NC, Leal G, Muehlberger LE, Weaver SC: Infection and dissemination of Venezuelan equine encephalitis virus in the epidemic mosquito vector, Aedes taeniorhynchus. Am J Trop Med Hyg 2007, 7(1):176-187.

18. Kramer LD, Hardy $J$, Presser SB, Houk EJ: Dissemination barriers for western equine encephalomyelitis virus in Culex tarsalis infected after ingestion of low viral doses. Am J Trop Med Hyg 1981, 30(1):190-197.

19. Merrill MH, Tenbroeck C: The transmission of equine encephalomyelitis virus by Aedes aegypti. J Exp Med 1935, 62(5):687-695.

20. Nye ER: Artificial infection of Aedes aegypti with Semliki Forest virus by intrahaemocoelic injection. Trans R Soc Trop Med Hyg 1961, 55:459-462.

21. Hardy JL, Reeves WC, Sjogren RD: Variations in the susceptibility of field and laboratory populations of Culex tarsalis to experimental infection with western equine encephalomyelitis virus. Am J Epidemiol 1976, 103(5):498-505.

22. Miles JA, Pillai JS, Maguire T: Multiplication of Whataroa virus in mosquitoes. J Med Entomol 1973, 10(2):176-185.

23. Hardy JL, Apperson G, Asman SM, Reeves WC: Selection of a strain of Culex tarsalis highly resistant to infection following ingestion of western equine encephalomyelitis virus. Am J Trop Med Hyg 1978, 27(2 Pt 1):313-321.

24. Green DW, Rowley WA, Wong YW, Brinker JP, Dorsey DC, Hausler WJ Jr: The significance of western equine encephalomyelitis viral infections in Aedes trivittatus (Diptera: Culicidae) in lowa. I. Variation in susceptibility of Aedes trivittatus to experimental infection with three strains of western equine encephalomyelitis virus. Am J Trop Med Hyg 1980, 29(1):118-124.

25. Scherer WF, Cupp EW, Lok JB, Brenner RJ, Ordonez JV: Intestinal threshold of an enzootic strain of Venezuelan encephalitis virus in Culex (Melanoconion) taeniopus mosquitoes and its implications to vector competency and vertebrate amplifying hosts. Am J Trop Med Hyg 1981, 30(4):862-869.

26. Schiefer BA, Smith JR: Comparative susceptibility of eight mosquito species to Sindbis virus. Am J Trop Med Hyg 1974, 23(1):131-134.

27. Mangiafico JA: Chikungunya virus infection and transmission in five species of mosquito. Am J Trop Med Hyg 1971, 20(4):642-645.

28. Collins WE: Studies on the transmission of Semliki Forest virus by anopheline mosquitoes. Am J Trop Med Hyg 1963, 77:109-113.

29. Coffey LL, Vasilakis N, Brault AC, Powers AM, Tripet F, Weaver SC: Arbovirus evolution in vivo is constrained by host alternation. Proc Natl Acad SCi U S A 2008, 105(19):6970-6975.

30. Weaver SC, Brault AC, Kang W, Holland JJ: Genetic and fitness changes accompanying adaptation of an arbovirus to vertebrate and invertebrate cells. J Virol 1999, 73(5):4316-4326.

31. Coffey LL, Vignuzzi M: Host alternation of chikungunya virus increases fitness while restricting population diversity and adaptability to novel selective pressures. J Virol 2011, 85(2):1025-1035.

32. Vasilakis N, Deardorff ER, Kenney JL, Rossi SL, Hanley KA, Weaver SC: Mosquitoes put the brake on arbovirus evolution: experimental evolution reveals slower mutation accumulation in mosquito than vertebrate cells. PLoS Pathog 2009, 5(6):e1000467.

33. Deardorff ER, Fitzpatrick KA, Jerzak GV, Shi PY, Kramer LD, Ebel GD: West Nile virus experimental evolution in vivo and the trade-off hypothesis. PLoS Pathog 2011, 7(11):e1002335.

34. Moutailler S, Roche B, Thiberge JM, Caro V, Rougeon F, Failloux AB: Host alternation is necessary to maintain the genome stability of rift valley fever virus. PLoS Negl Trop Dis 2011, 5(5):e1156.

35. Bowers DF, Abell BA, Brown DT: Replication and tissue tropism of the alphavirus Sindbis in the mosquito Aedes albopictus. Virology 1995, $10(212(1)): 1-12$. 
36. Kelly EM, Moon DC, Bowers DF: Apoptosis in mosquito salivary glands: Sindbis virus-associated and tissue homeostasis. J Gen Virol 2012, 93(Pt 11):2419-2424

37. Ahn A, Schoepp RJ, Sternberg D, Kielian M: Growth and stability of a cholesterol-independent Semliki Forest virus mutant in mosquitoes. Virology 1999, 30(262(2)):452-456

38. Dhileepan K, Azuolas JK, Gibson CA: Evidence of vertical transmission of Ross River and Sindbis viruses (Togaviridae: Alphavirus) by mosquitoes (Diptera: Culicidae) in southeastern Australia. J Med Entomol 1996, 33:180-182.

39. Fulhorst CF, Hardy JL, Eldridge BF, Presser SB, Reeves WC: Natural vertical transmission of western equine encephalomyelitis virus in mosquitoes. science 1994, 263:676-678.

40. Lindsay MD, Broom AK, Wright AE, Johansen CA, Mackenzie JS: Ross River virus isolations from mosquitoes in arid regions of Western Australia: implication of vertical transmission as a means of persistence of the virus. Am J Trop Med 1993, 49:686-696.

41. Kay BH: Three modes of transmission of Ross River virus by Aedes vigilax (Skuse). Aust J Exp Biol Med Sci 1982, 60:339-344.

42. Mavale M, Parashar D, Sudeep A, Gokhale M, Ghodke Y, Geevarghese G, Arankalle $V$, Mishra AC: Venereal transmission of chikungunya virus by Aedes aegypti mosquitoes (Diptera: Culicidae). Am J Trop Med Hyg 2010, 83(6):1242-1244

43. Ovenden JR, Mahon RJ: Venereal transmission of Sindbis virus between individuals of Aedes australis (Diptera: Culicidae). J Med Entomol 1984, 21(3):292-295.

44. Haddow AD, Guzman H, Popov VL, Wood TG, Widen SG, Haddow AD, Tesh $\mathrm{RB}$, Weaver SC: First isolation of Aedes flavivirus in the Western Hemisphere and evidence of vertical transmission in the mosquito Aedes (Stegomyia) albopictus (Diptera: Culicidae). Virology 2013, 440(2):134-139.

45. Saiyasombat R, Bolling BG, Brault AC, Bartholomay LC, Blitvich BJ: Evidence of efficient transovarial transmission of Culex flavivirus by Culex pipiens (Diptera: Culicidae). J Med Entomol 2011, 48(5):1031-1038.

46. Bolling BG, Eisen L, Moore CG, Blair CD: Insect-specific flaviviruses from Culex mosquitoes in Colorado, with evidence of vertical transmission. Am J Trop Med Hyg 2011, 85(1):169-177.

47. Samina I, Margalit J, Peleg J: Isolation of viruses from mosquitoes of the Negev, Israel. Trans R Soc Trop Med Hyg 1986, 80(3):471-472.

48. Haddow AJ, Davies CW, Walker AJ: O'nyong nyong fever: an epidemic virus disease in East Africa: Introduction. Trans R Soc Trop Med Hyg 1960, 54:517-522.

49. Williams MC, Woodall JP, Corbet PS, Gillett JD: O'nyong-nyong fever: an epidemic virus disease in East Africa. VIII. Virus isolations from Anopheles mosquitoes. Trans R Soc Trop Med Hyg 1965, 59:300-306.

50. Williams MC, Woodall JP: O'nyong nyong fever: an epidemic virus disease in east Africa: isolation and some properties of the virus. Trans $R$ Soc Trop Med Hyg 1961, 55:135-141.

51. Johnson BK, Gichogo A, Gitau G, Patel N, Ademba G, Kirui R: Recovery of O'nyong nyong virus from Anopheles funestus. Trans R Soc Trop Med Hyg 1981, 75:239-241.

52. Systematic catalog of Culicidae compiled and maintained by the Walter Reed Biosystematics Unit. http://www.mosquitocatalog.org/default.aspx.

53. Adugna N, Petros B: Determination of the human blood index of some anopheline mosquitos by using ELISA. Ethiop Med J 1996, 34(1):1-10.

54. Muriu SM, Muturi EJ, Shililu JI, Mbogo CM, Mwangangi JM, Jacob BG, Irungu LW, Mukabana RW, Githure JI, Novak RJ: Host choice and multiple blood feeding behaviour of malaria vectors and other anophelines in Mwea rice scheme, Kenya. Malar J 2008, 7:43.

55. Fornadel CM, Norris LC, Franco V, Norris DE: Unexpected anthropophily in the potential secondary malaria vectors Anopheles coustani s.l. and Anopheles squamosus in Macha, Zambia. Vector Borne Zoonotic Dis 2011, 11(8):1173-1179.

56. Gilles MT: The role of secondary vectors of malaria in North-East Tanganyika. Trans R Soc Trop Med Hyg 1964, 58:154-158.
57. Antonio-Nkondjio C, Kerah CH, Simard F, Awono-Ambene P, Chouaibou M, Tchuinkam T, Fontenille D: Complexity of the malaria vectorial system in Cameroon: contribution of secondary vectors to malaria transmission. J Med Entomol 2006, 43(6):1215-1221.

58. Mwangangi JM, Muturi EJ, Muriu SM, Nzovu J, Midega JT, Mbogo C: The role of Anopheles arabiensis and Anopheles coustani in indoor and outdoor malaria transmission in Taveta District, Kenya. Parasit Vectors 2013, 6:114.

\section{Submit your next manuscript to BioMed Central and take full advantage of:}

- Convenient online submission

- Thorough peer review

- No space constraints or color figure charges

- Immediate publication on acceptance

- Inclusion in PubMed, CAS, Scopus and Google Scholar

- Research which is freely available for redistribution 